\title{
Agreement morphology errors and null subjects in young (non-)CLIL learners
}

\author{
Yolanda Fernández-Pena \\ Departamento de Filología \\ Universidad de Cantabria, Spain \\ yolanda.fernandezpena@unican.es \\ Francisco Gallardo-del-Puerto \\ Departamento de Filología \\ Universidad de Cantabria, Spain \\ francisco.gallardo@unican.es
}

\begin{abstract}
There is a wealth of studies on L2 English acquisition in CLIL contexts in Spain, but most have underexplored the potential impact of CLIL in the longer run on the morphosyntax of earlier starters from monolingual regions. This paper fills this gap by exploring agreement morphology errors and subject omission in the oral production of Primary Education English learners from the Spanish monolingual community of Cantabria. The sample investigated consists of the individual narration of a story by learners in two age-matched (11-12 year-olds) groups, one CLIL $(n=28)$ and one nonCLIL ( $n=35)$. The results show no statistically significant differences between both groups for the provision of specific linguistic features at a younger age, though some evidence also points to a subtle effect of additional CLIL exposure. Both groups show moderately low rates of null subjects; they omit affixal morphology (*he eat) significantly more frequently than suppletive inflection (*he _eating) and they seldom produce commission errors ( ${ }^{*}$ they eats). Interestingly, non-CLIL learners show far greater rates of omission with auxiliary be than copula be and frequently use the placeholder is ( is eat), which evinces an earlier stage of acquisition than that of CLIL learners.
\end{abstract}

Keywords: CLIL, L2 English, Primary Education, inflectional morpheme error, null subject

\section{Resumen}

En estudios previos sobre la adquisición de inglés como L2 en contextos AICLE en España no se ha explorado en profundidad el impacto potencial de AICLE en la morfosintaxis en estudiantes con una exposición temprana y prolongada a la lengua 
meta y en regiones monolingües. Nuestra investigación contribuye a esta línea de investigación explorando los errores de morfología flexiva y la omisión del sujeto en la producción oral de aprendices de inglés de Educación Primaria de la comunidad española monolingüe de Cantabria. La muestra investigada consiste en la narración individual de una historia por aprendices de edades similares de un grupo CLIL $(n=28)$ y uno no CLIL $(n=35)$. Los resultados no muestran diferencias significativas entre ambos grupos en lo que respecta a la provisión de rasgos lingüísticos específicos a edades tempranas, aunque sí evidencian un ligero efecto de la exposición adicional a AICLE. Ambos grupos muestran tasas relativamente bajas de sujetos nulos; omiten la morfología afijal (*he eat_) con una frecuencia significativamente mayor que la supletiva (*he _ eating) y raramente emplean morfemas flexivos de forma errónea ( ${ }^{*}$ they eats). Sin embargo, los estudiantes de programas tradicionales omiten más el auxiliar be que la cópula be y utilizan más frecuentemente el 'comodín' is ( una etapa de adquisición más temprana que la de los estudiantes en programas AICLE.

Palabras clave: AICLE, inglés L2, Educación Primari,; error de morfología flexiva, sujeto nulo

\section{Introduction}

Research on the acquisition of L2 English has reported great difficulties and problems with the acquisition of properties that pertain to various domains of language, as is the case of the properties related to the syntax-morphology interface (Gutiérrez-Mangado \& Martínez-Adrián, 2018; Montrul, 2011; Slabakova, 2008; White, 2003a). Content and Language Integrated Learning (henceforth CLIL) programmes have been recently implemented in Spain in an attempt to promote and increase learners' proficiency in English through additional exposure to the target language in the curriculum. The main asset of this educational approach is not only the increase in the hours of exposure to the target language but also the input that CLIL learners receive. It is more natural and communicatively more meaningful and authentic, as language is used for interactional purposes (see Gutiérrez-Mangado \& Martínez-Adrián, 2018; Lázaro \& García Mayo, 2012; Martínez Adrián \& Gutiérrez Mangado, 2015b). Research hitherto, however, has confirmed that, while CLIL programmes prove to exert a positive impact on the learners' average proficiency in English (e.g. Jiménez Catalán et al., 2006 and Navés \& Victori, 2010 for Primary Education; Lasagabaster, 2008; Martínez Adrián \& Gutiérrez Mangado, 2015a; Ruiz de Zarobe, 2008, among others, for Secondary Education), some more specific aspects of the language such as pronunciation (Gallardo del Puerto et al., 2009; Ruiz de Zarobe, 2007) and morphosyntax (Lázaro Ibarrola, 2012; Martínez Adrián \& Gutiérrez Mangado, 2009, 2015a; Villarreal Olaizola, 2011) do not seem to benefit so clearly 
from CLIL approaches (for a discussion, see Gallardo del Puerto \& Martínez Adrián, 2013; Dalton-Puffer, 2008; Martínez Adrián, 2011 and Ruiz de Zarobe, 2011). Two cases in point are the production of agreement morphology errors and null subjects illustrated in (1) to (3) (here 'error' is used for non-native-like forms in consistency with prior generative approaches to the acquisition of L2 morphosyntax (e.g. García Mayo \& Villarreal Olaizola, 2009; Villarreal Olaizola, 2011 and Villarreal Olaizola \& García Mayo, 2009). For these types of errors, the evidence provided thus far precludes categorical conclusions on a potential advantage of additional CLIL exposure and on a subsequently more target-like performance of CLIL learners over learners receiving only traditional English as a Foreign Language (EFL) lessons.

(1) a. *the mother prepare food to the dog [CLIL I: subject 43]

b. *Tim and parent eeh is welcomed the house [non-CLIL: subject 169]

(2) *the dad Ø running to the bathroom [CLIL I: subject 50]

(3) a. *because Ø see raining [CLIL II: subject 80]

b. *because $\varnothing$ is raining [non-CLIL: subject 186]

Our study delves into this issue with a view to shed more light into the potential impact of additional CLIL exposure on the oral production of these types of errors by young (11- and 12-year-old) Spanish learners of L2 English from three Primary Schools in Cantabria, two of them implementing CLIL programmes and the third one providing just traditional EFL instruction. The paper is organised as follows: first, Section 2 reviews previous literature and studies on the acquisition of the English agreement morphology and the obligatory use of overt subjects, particularly in CLIL and non-CLIL contexts. Section 3 describes the aims and the research questions of our study and Section 4, the specifics of the methodology. Section 5 reports and discusses the data obtained from the analysis of both agreement morphology errors and null subjects. Finally, Section 6 presents the main conclusions and the limitations of the study, and suggests some lines for further research.

\section{Theoretical background}

\subsection{The acquisition of agreement morphology and obligatory subjects}

Omission of inflectional morphology, as in (1a) above, is not exclusive to L2 English learners. In the early grammar of children acquiring English as an L1 there is also a stage at which they omit agreement morphemes (Brown, 1973; Rizzi, 1993; 
see also Ionin \& Wexler, 2002 for a review). Although English falls into the category of languages which require an overt grammatical or lexical subject or, in Generativist terms, it is a 'non-pro-drop' language (Chomsky, 1981), this early grammar is also characterised by the production of null referential and expletive subjects, as in (3a) and (3b) above, respectively (Hyams, 1989). Some authors maintain that the L1 learners' consistent production of finiteness markers on verbal forms has been found to correlate with the consistent provision of overt subjects (Guilfoyle, 1984), and some others note that for that developmental stage it is essential to have acquired expletive subjects first, as it is the child's awareness of the need to provide these purely grammatical subjects that facilitates their systematic production and, subsequently, that of referential subjects (Hyams, 1989; see also Ruiz de Zarobe, 1997, 1998, 2000). As regards L1 English inflectional morphology, little difficulties have been claimed, except for its possible omission, but no evidence has been found for the incorrect production of agreement morphology errors (i.e. 'commission errors') as in (1b) above (see Brown, 1973; Ionin \& Wexler, 2002; Zobl \& Liceras, 1994). Finally, unlike in L2 English, research has shown that in the acquisition of L1 English both suppletive and affixal finiteness morphemes "cluster close together in development" (Ionin \& Wexler, 2002, p. 102; Zobl \& Liceras, 1994).

In the acquisition of L2 English, which is the focus of this paper, it has been widely attested that adult learners of English with 'pro-drop' L1s (i.e. with an L1 which accepts the omission of the subject), such as Spanish, transfer certain aspects of the null subject parameter in their L1 to their L2 grammar (White, 1986, 1989, 2003b). Subject omission - as in (4) and (5) - is to be expected particularly at earlier stages of L2 English acquisition (see Phinney, 1987 on adult L2 grammar; cf. Haznedar, 2001; Ionin \& Wexler, 2002 on child L2 English learners and White, 2003a on one adult learner), though expletive subjects (4) have been found to be problematic even for advanced adult L2 learners (Ruiz de Zarobe, 1998).

(4) *in the city $\varnothing$ is cloudy and sunny [non-CLIL: subject 162]

(5) *because $\varnothing$ is in city in the morning [non-CLIL: subject 169]

Acquiring the obligatory use of overt subjects in L2 English entails certain difficulty for learners with pro-drop L1s, as there is a greater cost involved in resetting the 'unmarked' (i.e. pro-drop) value of the null subject parameter in languages like Spanish to the 'marked' non-pro-drop English parameter (Phinney, 1987). An additional factor which complicates the resetting of this parameter and the Spanish learners' acquisition of obligatory subjects in L2 English is the extensive use of purely grammatical and semantically empty expletive subjects in English, unlike in Spanish, which do not have to meet the interpretative identification requirement criteria of null 
subjects (6) (e.g. on adult learners, see Judy, 2011; Judy \& Rothman, 2010; Phinney, 1987; Ruiz de Zarobe, 1997, 1998, 2000). Unlike in L1 English, where it is expletive subjects that have a leading role in the readjustment of the pro-drop parameter, the acquisition of expletive subjects by Spanish learners of English is quite late. In fact, with adult learners it has been observed to be delayed until referential subjects and auxiliary and modal verbs are acquired, with the acquisition of the progressive auxiliary being the actual trigger of the readjustment of the pro-drop parameter in L2 English (Ruiz de Zarobe, 1998).

(6) It is cloudy and sunny

*ello está nublado y soleado

As concerns the acquisition of English inflectional morphology, L2 English learners have been found to have great difficulties with inflectional morphemes, especially in spoken production (Ionin, 2013). This is, in fact, a widespread and frequent error in the acquisition of English as a foreign language irrespectively of the learners' L1 (see García Mayo \& Villarreal Olaizola, 2011). Previous research has shown that adult non-native speakers of English tend to be quite inconsistent in their production of English verbal inflection and often resort to uninflected forms as the default option (García Mayo \& Villarreal Olaizola, 2011; Ionin, 2013), as illustrated by protect and look in (7) and (8). Variability in the production of agreement morphology is claimed to persist even if a high level of proficiency in the target language is achieved (Lardiere, 2000).

(7) *he protect the dog for the rain [non-CLIL: subject 162]

(8) *the person look at the dog [CLIL II: subject 75]

The asymmetry between the acquisition of suppletive and affixal morphology is another characteristic of the L2 learners' grammar that differs from the acquisition of L1 English and has attracted a great deal of the scholarly attention (García Mayo \& Villarreal Olaizola, 2011; Ionin \& Wexler, 2002; Villarreal Olaizola, 2011; Villarreal Olaizola \& García Mayo, 2009; Zobl \& Liceras, 1994). These studies have observed how suppletive inflection is provided with a greater frequency than affixal morphology, with an earlier emergence and mastery of copula be compared to auxiliary be.

From a very broad perspective, L2 learners' agreement morphology errors and null subjects can be explained under the lens of two main generativist proposals, both of them with a range of specific variants (see Ionin, 2013; Slabakova, 2008 and White, $2003 \mathrm{~b}$ for a review). On the one hand, there are scholars who claim that errors result from a global or more local representational impairment in functional categories and 
feature values (e.g. Goad et al., 2003; Hawkins \& Casillas, 2008; Hawkins \& Chan, 1997; Tsimpli \& Dimitrakopoulo, 2007). Under this view, "learners are incapable of acquiring new features in the L2 that are not present in their L1" (Ionin, 2013: 507). Age seems to play a decisive role in this account, as it predicts that formal features that are unspecified in the $\mathrm{L} 1$ will not be accessible to adult learners and this will inevitably derive in syntactic deficits in the L2 (García Mayo \& Villarreal Olaizola, 2011).

On the other hand, there are scholars who contend that the learners' L2 is not impaired and attribute variability and errors to different factors such as a mapping problem between abstract features and their corresponding morphological form or problems with the specifications and selection/reassembly of those features (e.g. Haznedar \& Schwartz, 1997; Ionin \& Wexler, 2002; Lardiere, 2008, 2009; Prévost \& White, 2000; for a review of these approaches, see Villarreal Olaizola, 2011). Evidence for this stand comes, for instance, from the fact that both child and adult L2 English learners have proved to have the agreement category in their grammar: despite having difficulties supplying the correct morphological form, particularly in the case of affixal inflection, they do tend not to misuse verbal inflection unsystematically (García Mayo \& Villarreal Olaizola, 2011; Ionin, 2013; Villarreal Olaizola, 2011). If their L2 grammar suffered from a representational impairment at the level of syntactic representation, commission errors, as in (1b) above, would be higher (Ionin \& Wexler, 2002). Research on subject features also confirms that even adult L2 grammars are not impaired: although the L2 features that are not present in their L1 do not seem to be fully acquired, learners do show learning development with increased exposure when confronted with grammaticality judgments by rejecting null expletive subjects (as in (4)) to a larger extent (Pladevall Ballester, 2013).

\subsection{CLIL in Spain and the acquisition of specific morphosyntactic features}

As already mentioned, one approach that has been advocated and implemented in the Spanish context to improve L2 English learners' proficiency in the target language involves additional exposure to English through so-called 'CLIL programmes' (Marsh, 2002). Content and Language Integrated Learning or CLIL, coined in 1994 (Marsh, 1994), is an umbrella term that encompasses those approaches "in which a second language (a foreign, regional or minority language and/or another official state language) is used to teach certain subjects in the curriculum other than language lessons themselves" (Eurydice, 2006: 8). Accordingly, in CLIL approaches, while there may be support for the L1 and the classroom culture is that of the L1, it is mainly the target language that is used as a medium of instruction. The learners' knowledge of the target language is most commonly limited but teachers are assumed to be sufficiently competent, as the L2 curriculum has to parallel that of the L1 (Martínez Adrián, 2011). 
CLIL is thus a dual-focused approach where the L2 is integrated in the curriculum to teach content classes while content is on some occasions integrated in the language classes (Martínez Adrián, 2011; Ruiz de Zarobe, 2011).

There is no doubt that CLIL has postulated itself as a very convenient, effective method to compensate for the frequently low number of hours of instruction in the target language in countries like Spain, where the popularity of CLIL has increased in the last decades to the extent that it is considered one of the European leaders in both its implementation and its research (Coyle, 2010; Martínez Adrián, 2011; PérezCañado, 2012). In the case of CLIL in Spain, its implementation is characterised by, on the one hand, the wide range of CLIL programmes, which vary depending on the autonomous region, and, on the other, the integration of the target language in monolingual or bilingual communities (Galicia, Basque Country, Catalonia, Valencia and the Balearic Islands) (Martínez Adrián, 2011; Pérez-Cañado, 2012). The impact of CLIL on Spanish bilingual regions has attracted the attention of many scholars and a great bulk of the research on the topic (e.g. for the Basque Country, see e.g. García Mayo \& Villarreal Olaizola, 2011; Gutiérrez-Mangado \& Martínez-Adrián, 2018; Lázaro Ibarrola, 2012; Martínez Adrián \& Gutiérrez Mangado, 2009, 2015a, 2015b; Ruiz de Zarobe \& Lasagabaster, 2010 and Villarreal Olaizola, 2011; for Galicia, San Isidro, 2010; San Isidro \& Lasagabaster, 2019a, 2019b, and for the Catalan territories, Aguilar \& Muñoz, 2014; Juan-Garau \& Pérez-Vidal, 2011; Navés \& Victori, 2010; Pérez-Vidal, 2007, Pérez-Vidal \& Juan-Garau, 2010, 2011; and Pérez-Vidal \& Roquet, 2015). In contrast, monolingual communities such as the region explored in this investigation, Cantabria, have received less attention in the literature (e.g. Gutiérrez Martínez \& Ruiz de Zarobe, 2017; Merino \& Lasagabaster, 2018; for further references, see Fernández Fontecha, 2009 and Pérez-Cañado, 2012). In addition to this, another reason to explore the production of learners from monolingual regions concerns their disadvantageous position with respect to the greater metalinguistic awareness of L3 English learners from bilingual communities (Jessner, 2014).

Overall, research on CLIL contexts in Spain has demonstrated that the greater exposure to the target language that CLIL grants typically benefits the learners' overall proficiency in English. CLIL learners have been found to perform more target-like than non-CLIL groups in oral and written fluency, syntactic complexity, reading comprehension and receptive vocabulary, for instance (for Primary Education, see Jiménez Catalán et al., 2006 and Navés \& Victori, 2010; for Secondary Education, Gutiérrez-Mangado \& Martínez-Adrián, 2018; Lasagabaster, 2008; Ruiz de Zarobe, 2008). Nonetheless, for the acquisition of more specific areas of the target language the evidence obtained is less conclusive and the potential positive impact of CLIL more dubious. A case in point is the syntax-morphology interface. Some studies do attest an advantage in CLIL groups (compared to learners with only EFL instruction) as regards 
the acquisition of certain morphosyntactic aspects such as irregular past forms (Lázaro Ibarrola, 2012), syntactic complexity and article use (Gutiérrez-Mangado \& MartínezAdrián, 2018), affixal compared to suppletive inflection (Villarreal Olaizola \& García Mayo, 2009) and placeholders (Martínez Adrián \& Gutiérrez Mangado, 2009). Despite these results, all based on data from teenage L2 learners, most of the research carried out hitherto has observed minimal differences between age-matched CLIL and non-CLIL groups in their rate of agreement morphology errors and subject omission (García Mayo \& Villarreal Olaizola, 2011; Martínez Adrián \& Gutiérrez Mangado, 2009, 2015a; Villarreal Olaizola, 2011). Some of these investigations, however, do find remarkable differences in the production of the different inflectional forms and subjects, as is commented in detail below.

Verb inflection is claimed to be the 'bottleneck' of L2 acquisition (see Slabakova, 2008). Omission of suppletive forms and, particularly, affixal verb morphology is a very frequent phenomenon in both child and adult L2 English grammars (Ionin, 2013). As commented above, affixal inflection (9) is not only highly variable but also more frequently omitted than suppletive verbal forms (10) because the latter are acquired at earlier stages of the acquisition of L2 English. This has been attested in both CLIL and non-CLIL groups at Secondary School (García Mayo \& Villarreal Olaizola, 2011; cf. Villarreal Olaizola \& García Mayo, 2009 on the more target-like performance of CLIL learners and Villarreal Olaizola, 2011 on the disappearance of that advantage a year after the CLIL programme is over). Non-CLIL learners, however, have been found to have greater problems with the production of not only affixal inflection but also auxiliary be compared to copula be (Villarreal Olaizola, 2011). This well-known dissociation between the acquisition of affixal and suppletive inflection seems to be rooted in the different process whereby auxiliary and copula be check their tense and agreement features: whereas lexical verbs features are checked covertly and, thus, their inflection "may or may not be expressed morphologically, depending on languagespecific rules", the feature checking of to be is overt and is expressed morphologically, which entails fewer complications for L2 learners (see García Mayo \& Villarreal Olaizola, 2011, pp. 132-134 for further discussion and references).

(9) *that the boy eeeh take the dog in his house [CLIL II: subject 77]

(10) *the dog eeeh Ø hungry [CLIL I: subject 39]

In contrast, commission errors such as (11) and (12) are most often negligible. The few studies carried out on CLIL and non-CLIL teenage learners of L2 English attest a very low incidence of this type of errors in both groups, thus claiming that they are not representative of these learners' interlanguage (García Mayo \& Villarreal Olaizola, 2011; Villarreal Olaizola, 2011; Villarreal Olaizola \& García Mayo, 2009). 
(11) *her mother and her father eeeh sees happiness [CLIL II: subject 77]

(12) * in the book are there one dog in the town [CLIL I: subject 43]

The use of placeholders, that is, the use of a suppletive form - often is (13) or he (14) - before the (bare) main verb to hold its inflection is another characteristic of Spanish L2 English learners' interlanguage, particularly in their earlier stages of acquisition (also in L1 English, see Lázaro Ibarrola, 2002, 2012). This mechanism, which is assumed to result from L1 transfer of functional categories (see Martínez Adrián \& Gutiérrez Mangado, 2009), is attested in the literature mainly in non-CLIL groups as a sign of their less advanced stage of acquisition of English (see Lázaro Ibarrola, 2012 and Martínez Adrián \& Gutiérrez Mangado, 2009 for data from Secondary Education; for data from non-CLIL contexts, see García Mayo et al., 2005 and Lázaro Ibarrola, 2002).

(13) *the dog is walk in the city [non-CLIL: subject 179]

(14) *when the the child he's coming [CLIL I: subject 41]

Finally, subject omission is expected to be found in Spanish learners of L2 English given the pro-drop nature of the Spanish language. In general terms, no significant differences between CLIL and (age-matched as well as older) non-CLIL teenage learners have been attested, although the latter have been found to produce more null subjects (Martínez Adrián \& Gutiérrez Mangado, 2009, 2015a). Research in EFL contexts has observed in Spanish adult oral and written production that null subjects are more frequent in earlier stages of acquisition, with their omission and acceptance decreasing with increasing proficiency in the L2 (see Ortega Durán, 2016; Ruiz de Zarobe, 1997, 1998, 2000). Interestingly, some of the studies carried out in non-CLIL contexts have found that not all subjects are acquired at the same time. The evidence from adult L2 English written production provided in Judy (2011), Judy and Rothman (2010), Phinney (1987) and Ruiz de Zarobe (1997, 1998, 2000), for instance, points to an earlier acquisition of obligatory referential subjects (15), compared to obligatory expletive subjects (16). Based on these results, a high rate of null subjects and variability with the provision of the different types of subjects can be expected in the L2 grammar of young CLIL learners (see García Mayo, 2003 on the problems of 11- and 12-year-olds to identify sentences with null subjects as ungrammatical after approximately four years of exposure to English in an EFL setting).

(15) *because no eh doesn't doesn't like raining $\varnothing$ doesn't like raining [non-CLIL: subject 169]

(16) *and de repent $\varnothing$ is ra raining [non-CLIL: subject 185] 


\section{Aims and research questions}

This study is not intended to corroborate or refute the theoretical approaches succinctly reviewed above but to delve into the production of agreement morphology errors and null subjects from a usage-based perspective. To this end, we will analyse the oral production of L2 English learners from three Primary Schools in Cantabria, two of them implementing CLIL programmes and the third one providing just traditional EFL instruction, with the aim of shedding more light into the potential impact of an early and long-term CLIL exposure, compared to an early traditional EFL instruction, on L2 English morphosyntax. In EFL contexts, an earlier start has been claimed not to be always an advantage (Cadierno et al., 2020; Muñoz, 2006), especially if the amount of exposure is not increased or used effectively (García Mayo, 2003; Muñoz, 2002). Still, Pladevall Ballester (2012) observes that Spanish 5 year-olds attending an immersion school for two years were sensitive to grammaticality judgments, and García Mayo (2003) with older subjects (11 to 17 year-olds), that an increased exposure in EFL instruction results in a more target-like performance. A positive impact of longerterm exposure has also been attested in CLIL contexts, with CLIL learners performing better than non-CLIL groups (e.g. Lasagabaster, 2008; and, for Primary Education, Jiménez Catalán et al., 2006) and older EFL groups (Navés \& Victori, 2010; Ruiz de Zarobe, 2008) in aspects other than morphosyntax. The studies reviewed in Section 2.2, especially those investigating agreement morphology, were mostly conducted in Secondary Education (with 13 to 18 year-olds) in Spanish bilingual communities (mainly the Basque Country), and compared the oral production of CLIL and (agematched or older) non-CLIL learners, with the former receiving an additional CLIL exposure to the target language of a maximum of three years. Their results suggest that the amount of exposure to the L2 may not be as relevant a factor as age when explaining morphological development: higher accuracy has been found in older learners, as the acquisition of the morphological system has been claimed to speed up at the age of 12-13 and to accelerate with the acquisition of the pronominal system at the age of 15 (see Lázaro Ibarrola, 2012; Lázaro \& García Mayo, 2012; Martínez Adrián \& Gutiérrez Mangado, 2015a; Villarreal Olaizola, 2011). Prior research has thus underexplored the potential impact of an earlier and longer-term CLIL exposure to the target language on the realisation of specific morphosyntactic aspects of younger Spanish learners of L2 English from monolingual communities, a gap that this investigation comes to bridge.

In particular, this paper aims at exploring agreement morphology errors and subject omission in Primary Education Grade 6 English learners from Cantabria with a view to further assess the potential benefit of additional CLIL exposure on L2 English morphosyntax in the longer run. Our investigation contributes to previous research by surveying not only two underresearched areas, 11- and 12-year-old learners 
of English and a monolingual community in northern Spain, but also a group which has received a considerably large additional exposure to the target language through a CLIL programme of approximately six years. The main objective is thus to gauge the extent to which an earlier and longer-term additional CLIL exposure translates into a potentially greater advantage in the provision of specific morphosyntactic aspects in comparison to (age-matched) non-CLIL learners who have also been exposed to the L2 for six years but have received traditional English lessons only. In the second place, our research also aims at examining potential differences in the production of agreement morphology errors and null subjects within each of the two groups surveyed.

Based on prior research and findings on the acquisition of verb inflection and overt subjects in L2 English, this investigation seeks to answer the following research questions:

1. Are there any differences between CLIL and non-CLIL learners in the production of agreement morphology errors and null subjects?

2. Are there any intragroup differences in CLIL and non-CLIL groups as regards

i. the omission of inflection compared to commission errors?

ii. the omission of affixal inflection compared to the omission of suppletive inflection?

iii. commission errors in affixal verbal morphology compared to commission errors in suppletive inflection?

iv. null referential subjects compared to null expletive subjects?

\section{Methodology}

\subsection{Participants}

The participants in this study were sixty-three Primary Education (Grade 6) students learning L2 English in three schools in the Spanish monolingual region of Cantabria. They constitute a subsample of all the learners from The Primary Education Learners' English Corpus (PELEC) (see Blanco-Suárez et al., 2020). As Table 1 shows, the students in the sample are divided into two age-matched (11- and 12-year-old) groups: the CLIL group $(n=28)$ and the non-CLIL group $(n=35)$. The English onset age for 
both the CLIL learners and the non-CLIL learners was around 5 and 6 years old. In the three Primary Schools, learners receive an estimated average of around 2.5 and 3.5 hours of English instruction per week, which amounts to a mean of 617.5 hours of English as a Foreign Language (EFL) lessons at the time the data were collected. Additionally, the students enrolled in CLIL programmes are taught several content classes - Arts and Crafts, Music, Natural Sciences, and Physical Education to be more precise - in the target language at an average of two or three hours a week. As a result, they had received a mean of 488 hours of additional exposure to English since Grade 1 until the time they participated in the study.

Table 1: Description of the sample

\begin{tabular}{lll}
\hline & CLIL & non-CLIL \\
\hline Participants & 28 & 35 \\
\hline Age at testing & $11-12$ & $11-12$ \\
English onset age & $5-6$ & $5-6$ \\
CLIL onset age & $5-6$ & none \\
\hline Hours of EFL per week & $2.5-3.5$ & $2.5-3.5$ \\
Mean hours of EFL at testing & 617.5 & 617.5 \\
\hline Hours of CLIL per week & $2-3$ & none \\
Mean hours of CLIL at testing & 488 & none \\
\hline
\end{tabular}

As for the participants' target language competence, both groups differ slightly in their level of English. Based on previous standardised tests that the Education Authorities administered at the end of Primary Education in the Autonomous Community of Cantabria, learners in CLIL schools were expected to reach, at best, the A2 level of the Common European Framework of Reference for Languages (CEFR) whereas schoolchildren in non-CLIL schools were examined for the A1 level. Learners in this study were administered some language tests (drawing on materials from the Cambridge English A1 Movers and A2 Flyers tests) prior to the collection of the data as part of a larger project that involves a greater number of schools and participants (see Blanco-Suárez et al., 2020 for further information). As for the subsample analysed in the present study, these tests revealed slightly superior mean scores of the CLIL group over their non-CLIL homologous in the listening comprehension, reading comprehension and, particularly, the Use of English modules. 


\subsection{Instruments and procedures}

This investigation draws on data from The Primary Education Learners' English Corpus (PELEC) (Blanco-Suárez et al., 2020). PELEC was compiled as part of a larger project which involved collecting learner data by means of several instruments: from foreign language motivation, communication strategies and background questionnaires to various written and (interactive) oral tasks (writing a letter, telling a story, spot-thedifferences) as well as listening comprehension, reading comprehension and Use of English (cloze) tests. The data reported in this paper focus on the oral production of the participants resulting from the oral task consisting of telling a story. In that task, the participants were asked to narrate individually a story based on the 8-vignette story illustrated in the Appendix. The task was recorded in the Primary Schools by one or two bilingual researchers, who, when necessary, guided the participants and answered their questions in English only. The participants' oral production was orthographically transcribed and analysed for the production of agreement morphology and obligatory subjects, as explained in detail below. The data were transcribed by two different researchers who had been previously trained to follow the CHAT conventions for the CLAN subprogramme in the Child Language Date Exchange System (CHILDES, MacWhinney, 2000). Two codifiers revised the transcriptions and identified the errors, showing a high degree of agreement. Any controversies or ambiguous cases were solved jointly on a case-by-case basis.

In keeping with Ionin and Wexler (2002), we considered as analysable utterances all those contexts where, in the case of agreement morphology, there was a finite or non-finite verb, where inflection was realised by either (i) a missing, correct or incorrect affix or (ii) a missing or overt suppletive form of the auxiliary or copula be. Regarding subject contexts, we analysed all the utterances where either a referential or an expletive subject was omitted. We excluded from the analysis instances involving:

(i) regular and irregular past tense lexical verbs: the dog eeeh he see (2") eeh he saw is raining [CLIL I: subject 41]

(ii) autocorrection: the boy eeh goes, no, go at your home [non-CLIL: subject 179]

(iii) the repetition of the same verbal form: his mom is cooking with (1") is cooking (2") is cooking. [CLIL I: subject 34]

(iv) an ambiguous referent: and the boy eeeh (3") eeeh at look the dog and dog eeeh (2") eeeh it's ha bueno is happy. and (6") eeeh and go to (1") to house. [CLIL I: subject 39] 
(v) an unclear form: the dog names [name's?] eeh Tim is go going to the city [nonCLIL: subject 169]

(vi) an unfinished utterance at the verb phrase level: the boy and the dog (1") going to (2") to (5") eeeh going to (12") $x x x$ eeeh going to (9") joer ahora no me sale nada [CLIL I: subject 39]

The type of utterances that we analysed in this investigation are exemplified in (17) to (21) below. In terms of verbal inflection, we considered instances which involve either the omission (17) or the commission (18) of the verbal morphology. More specifically, we analysed the omission and commission of both affixal (19) and suppletive inflection (20) in the present tense. In the case of suppletive forms, omission refers to the elision of be, as no uninflected forms of the auxiliary or the copula were attested in the sample surveyed. Finally, the use of placeholder is (21) as a resource to hold inflection was also investigated (see García Mayo et al., 2005; Lázaro Ibarrola, 2002, 2012; Martínez Adrián \& Gutiérrez Mangado, 2009). The use of placeholders in the subject, as in the wolf he opened the door, is not discussed here (see García Mayo et al., 2005), owing to the fact that only two tokens were attested in the sample, one in each of the research groups. For this reason, only placeholder is is considered.

(17) * the boy sleep with the dog [CLIL I: subject 46]

(18) *the dog and the boy goes to the bed to sleep [non-CLIL: subject 194]

(19) *and the dog eat [non-CLIL: subject 191]

(20) * the dad Ø running to the bathroom [CLIL I: subject 50]

(21) *one man is walk for the street [non-CLIL: subject 170]

Concerning subject contexts, we explored not only subject omission in general but also the omission of referential (22) compared to expletive (23) subjects.

(22) *because $\varnothing$ is in city [non-CLIL: subject 169]

(23) *because $\varnothing$ is raining [non-CLIL: subject 186]

The results from the quantitative analysis, which are reported in the next section, were subjected to statistical testing with SPSS.22. Mean scores (expressed as the mean percentage of errors derived from the relative number of errors made by every child over the number of potential contexts for those errors to happen) and standard deviations were calculated for the different morphosyntactic features and learner 
groups. Total number of contexts and mean number of contexts per learner are also reported. Kolmogorov-Smirnov tests were computed to explore the normality of the distribution of the samples. As the distribution of the samples was not normal, nonparametric procedures were used, namely Mann-Whitney $U$ tests for the intergroup comparisons and Wilcoxon tests for the intragroup ones. With regard to statistical significance, alpha levels of $.05\left(^{*}\right), .01\left(^{(*}\right)$ and $\left..0011^{(* *}\right)$ were used.

\section{Results and discussion}

This section is organised into three different parts. Firstly, to answer our first research question, we compare the rate of omission of inflection, commission errors and null subjects produced by CLIL learners with the results obtained in the nonCLIL group. Secondly, we explore intragroup differences with respect to the incidence of omission of inflection and commission errors as well as null subjects. In the final section, we provide an overall discussion of the results from both the inter- and the intragroup contrasts.

\subsection{Intergroup comparisons}

In this section, the results for affixal and suppletive inflection (both auxiliary be and copula be) are presented first, followed by those for subject contexts.

\subsubsection{Affixal and suppletive inflection}

Starting with affixal inflection, Table 2 reports the total number of contexts and the mean number of affixal contexts per learner, the total number of errors of each affixal type, the mean percent and the standard deviation (in brackets) of omission and commission errors as well as the use of placeholders by both CLIL and non-CLIL learners. Omission of inflection is by far the most common type of error in both groups, with CLIL learners omitting affixal inflection at a slightly higher rate (62.81\%) than their non-CLIL counterparts (53.63\%). Commission errors, in contrast, are very rare in general and more frequently produced by the non-CLIL group $(1.78 \%$ vs CLIL: $0.22 \%)$. These results, however, can only be taken as tendencies, as the intergroup differences in omission and commission did not reach statistical significance.

The use of placeholder is is also reported in Table 2. Both CLIL and non-CLIL groups made use of it, particularly the latter, which proved to overly realise inflection via a placeholder twice as frequently (19.52\%) as the CLIL group (9.79\%). Despite the apparent difference in the frequency in use of placeholders, the statistical test found no statistical support. 
Table 2: Absolute values, mean percent and standard deviation for omission and commission of affixal inflection and use of placeholders

Affixal inflection contexts CLIL non-CLIL

\begin{tabular}{lllll}
\hline $\begin{array}{l}\text { Total number of contexts } \\
\begin{array}{l}\text { Mean number of contexts } \\
\text { per learner }\end{array}\end{array}$ & 6.39 & & 180 & \\
\hline & Total & Mean \% (SD) & Total & Mean \% (SD) \\
\hline $\begin{array}{l}\text { Omission } \\
\text { *the boy sleep with the dog }\end{array}$ & 110 & $62.81 \%(31.69)$ & 106 & $53.63 \%(32.52)$ \\
$\begin{array}{l}\text { Commission } \\
{ }^{*} \text { they goes to the bed }\end{array}$ & 1 & $0.22 \%(1.18)$ & 5 & $1.78 \%(4.36)$ \\
$\begin{array}{l}\text { Placeholders } \\
*\end{array}$ the boy is sleep with the dog & 13 & $9.79 \%(21.03)$ & 30 & $19.52 \%(30.40)$ \\
\hline
\end{tabular}

Moving on to suppletive inflection, Table 3 reports the omission and the use of an incorrect form of auxiliary be. The data show that the production of a wrong form of the auxiliary is very unlikely and that it is only CLIL learners that produce one error of this type (1.59\%), which naturally renders the intergroup contrast non-significant. Likewise, the difference in the omission rate of the auxiliary between CLIL and nonCLIL learners did not reach statistical significance, although the latter were found to omit it at a greater extent (38.39\%) than the former (23.38\%). 
Table 3: Absolute values, mean percent and standard deviation for omission and commission of auxiliary be

\begin{tabular}{lllll}
\hline Auxiliary be contexts & CLIL & & non-CLIL \\
\hline $\begin{array}{l}\text { Total number of contexts } \\
\begin{array}{l}\text { Mean number of contexts } \\
\text { per learner }\end{array}\end{array}$ & 57 & & 69 & \\
\hline & Total & Mean \% (SD) & Total & Mean \% (SD) \\
\hline $\begin{array}{l}\text { Omission } \\
{ }^{*} \text { boy sleeping the dog }\end{array}$ & 9 & $23.38 \%(39.08)$ & 26 & $38.39 \%(42.99)$ \\
$\begin{array}{l}\text { Commission } \\
{ }^{*} \text { the dog are coming on the city }\end{array}$ & 1 & $1.59 \%(7.27)$ & 0 & $0.00 \%(0.00)$ \\
\hline
\end{tabular}

As in the previous two contexts, commission errors of copula be are remarkably rare in comparison to omission of inflection. Still, commission errors of the copula were found to be slightly more common than those of auxiliary be. Table 4 shows that CLIL learners are less target-like in their production of copula be than their non-CLIL homologous, as the former produce both more errors of commission (10.91\%) and a higher rate of omission (14.06\%) of the copula than non-CLIL learners (commission: $3.33 \%$; omission: $1.83 \%$ ). Despite these observations, no support from inferential statistics was found for this intergroup divergence.

Table 4: Absolute values, mean percent and standard deviation for omission and commission of copula be

\begin{tabular}{lllll} 
Copula be contexts & CLIL & non-CLIL \\
\hline $\begin{array}{l}\text { Total number of contexts } \\
\begin{array}{l}\text { Mean number of contexts per } \\
\text { learner }\end{array}\end{array}$ & 2.68 & & 52 & \\
\hline \multicolumn{1}{l}{ Total } & Mean \% (SD) & Total & Mean \% (SD) \\
\hline $\begin{array}{l}\text { Omission } \\
\text { the dog Ø with a bedroom }\end{array}$ & 7 & $14.06 \%$ (30.05) & 2 & $1.83 \%(5.67)$ \\
$\begin{array}{l}\text { Commission } \\
{ }^{*} \text { your eyes is brown }\end{array}$ & 8 & $10.91 \%$ (23.92) & 2 & $3.33 \%(11.60)$ \\
\hline
\end{tabular}


On the whole, the data presented in this section reveal minimal differences between CLIL and non-CLIL learners. Both groups omit and incorrectly provide affixal and suppletive inflection at similar rates and the problems of CLIL learners to provide copula be correctly were also found not to differ significantly from the commission rate of their non-CLIL homologous. In general terms, these non-significant differences between the performance of the CLIL group and that of its (age-matched) non-CLIL counterpart are in keeping with most of the research on older (i.e. teenage) L2 learners of English (see, for instance, Martínez Adrián \& Gutiérrez Mangado, 2009, 2015a; cf. Villarreal Olaizola, 2011 and Villarreal Olaizola \& García Mayo, 2009). One trend that somehow deviates from previous research is the CLIL group's use of placeholder is. Given the younger age of the participants in this study compared to prior investigations, this finding can be taken as an indication of their still early stage of acquisition of the L2 compared to older CLIL groups in previous studies (see Lázaro Ibarrola, 2012; Martínez Adrián \& Gutiérrez Mangado, 2009).

\subsubsection{Subject contexts}

The learners' rate of subject omission is presented in Table 5. Both the CLIL group and the non-CLIL group produce null subjects at a very similar rate, with the former's performance being slightly less target-like (10.40\%) than the latter's $(9.65 \%)$ in the overall rate of omission. By inspecting the data in detail, it can be observed that this difference, which in any case is not statistically significant, stems from the different performance of the groups with respect to the two possible types of subjects. Thus, whereas non-CLIL learners have greater difficulties to provide expletive subjects (63.46\% vs CLIL: $56.52 \%$ ), the rate of omission of referential subjects is slightly higher in the case of the CLIL group (3.53\% vs non-CLIL 2.41\%). As in the previous contexts under analysis, the differences between CLIL and non-CLIL learners did not reach statistical significance. 
Table 5: Absolute values, mean percent and standard deviation for subject omission

\begin{tabular}{|c|c|c|c|c|}
\hline Subject contexts & \multicolumn{2}{|l|}{ CLIL } & \multicolumn{2}{|c|}{ non-CLIL } \\
\hline $\begin{array}{l}\text { Total number of subject } \\
\text { (expletive/referential) } \\
\text { contexts }\end{array}$ & \multicolumn{2}{|c|}{$311(41 / 270)$} & \multicolumn{2}{|c|}{$301(38 / 263)$} \\
\hline \multirow{2}{*}{$\begin{array}{l}\text { Mean number of subject } \\
\text { (expletive/referential) } \\
\text { contexts per learner }\end{array}$} & \multicolumn{2}{|c|}{$11.11(1.46 / 9.64)$} & \multicolumn{2}{|c|}{$8.6(1.09 / 7.51)$} \\
\hline & Total & Mean \% (SD) & Total & Mean \% (SD) \\
\hline Overall subject omission & 33 & $10.40 \%(10.14)$ & 30 & $9.65 \%(9.82)$ \\
\hline $\begin{array}{l}\text { Omission expletive subjects } \\
{ }^{*} \text { because } \varnothing \text { is raining }\end{array}$ & 22 & $56.52 \%(42.66)$ & 23 & $\begin{array}{l}63.46 \% \\
(43.97)\end{array}$ \\
\hline $\begin{array}{l}\text { Omission referential } \\
\text { subjects } \\
\text { *because } \varnothing \text { is in the city }\end{array}$ & 12 & $3.53 \%(6.61)$ & 7 & $2.41 \%(6.94)$ \\
\hline
\end{tabular}

The overall moderately low rate of null subjects in both groups seems to point to an apparent mastery of obligatory subjects. This could be taken in principle as a sign of a more advanced acquisition stage, not being too far away from the low rate of null subjects produced by older learners in previous studies (Martínez Adrián \& Gutiérrez Mangado, 2009, 2015a).

\subsection{Intragroup comparisons}

To answer our second research question, this section scrutinises the data in more detail by exploring the types of features under analysis within each of the two groups.

\subsubsection{Omission of inflection vs commission errors}

Figure 1 illustrates the intragroup differences between the mean percent of omission and commission errors in both groups. The data confirm that the incidence of commission errors is negligible in comparison to omission of inflection, as discussed above. With both auxiliary be and affixal inflection, the rate of omission is exceedingly greater (auxiliary be: CLIL 23.38\%, non-CLIL 38.39\%; affixal: CLIL 62.81\%, nonCLIL 53.63\%) than that of commission (auxiliary be: CLIL 1.59\%, non-CLIL 0.00\%; 
affixal: CLIL 0.22\%, non-CLIL 1.78\%). Accordingly, the difference between these two trends is highly significant in both the CLIL (affixal inflection: $z=-4.465, p<.001^{* * *}$; auxiliary be: $z=-2.410, p=.016^{*}$ ) and the non-CLIL group (affixal inflection: $z=-4.629$, $p<.001^{* * *}$; auxiliary be: $\left.z=-3.351, p=.001^{* * *}\right)$.

Figure 1: Mean percent and Wilcoxon test results for omission of inflection vs commission errors

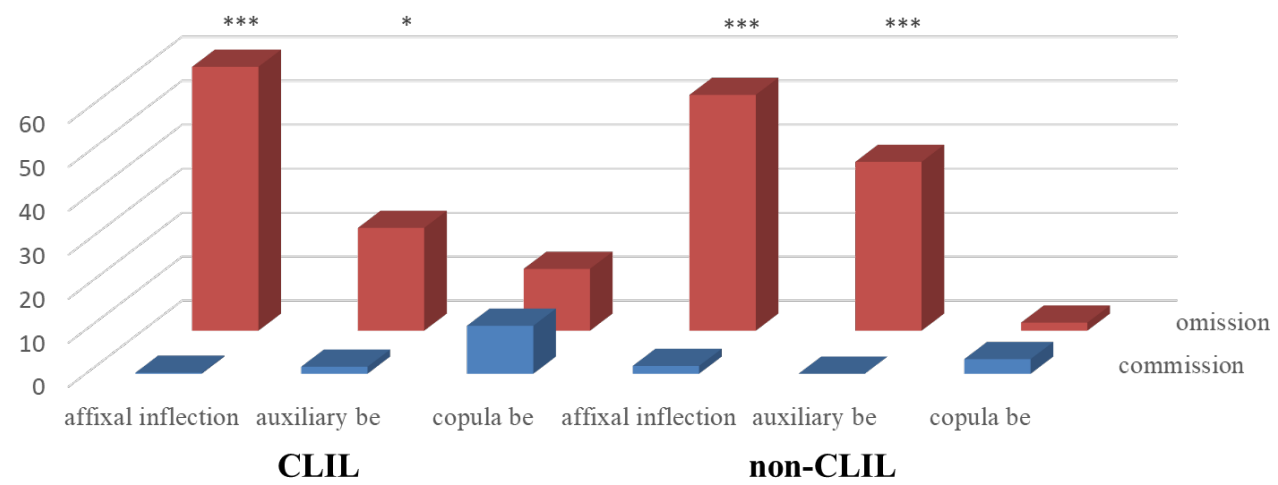

Interestingly, both groups show greater problems to supply the correct form of copula be than the rest of the forms investigated. The rate of commission errors with this suppletive form $(3.33 \%)$ is in fact more frequent than that of omission of inflection (1.83\%) in the non-CLIL group (in line with results from older L2 learners in Villarreal Olaizola \& García Mayo, 2009), but this intragroup contrast found no statistical support. The contrast is also non-significant in the case of the CLIL group, although in this case CLIL learners were found to be more likely to omit the copula $(14.06 \%)$ than produce an incorrect form $(10.91 \%)$. All the same, the commission rate of copula be in this group is considerably higher than that of affixal inflection and auxiliary be.

The fact that the overall marginal commission error rate, particularly in both affixal inflection and auxiliary be, contrasts significantly with the higher frequency of omission of inflection in the L2 English learners in this study is in keeping with the main trends attested in prior literature for older learners (García Mayo \& Villarreal Olaizola, 2011; Villarreal Olaizola \& García Mayo, 2009; Villarreal Olaizola, 2011). The evident difference in frequency between affixal and suppletive inflection observed in Figure 1 is discussed in more detail in the next section. 


\subsubsection{Omission of inflection}

Figure 2 elaborates on the previous results by focusing only on the omission rate in each of the three contexts analysed in both groups. The results for the CLIL group confirm the high frequency of omission of affixal inflection (62.81\%) compared to that of suppletive forms: the contrast between the former and copula be (14.06\%) was found to be highly significant $\left(z=-3.672, p<.001^{* * *}\right)$, while that between affixal inflection and auxiliary be (23.38\%) is only slightly significant $\left(z=-2.962, p=.003^{* *}\right)$. The evidence of the non-CLIL group reveals a very similar pattern, with the omission of copula be $(1.83 \%)$ being significantly lower than the omission rate of affixal inflection $(53.63 \%)\left(z=-3.705, p<.001^{* * *}\right)$. Auxiliary be omission $(38.39 \%)$ is significantly higher than that of copula be $\left(z=-2.555, p=.011^{*}\right)$ but not significantly different from affixal omission. CLIL learners, in contrast, were not found to omit auxiliary be and copula be at significantly different rates.

Figure 2: Mean percent and Wilcoxon test results for omission of inflection

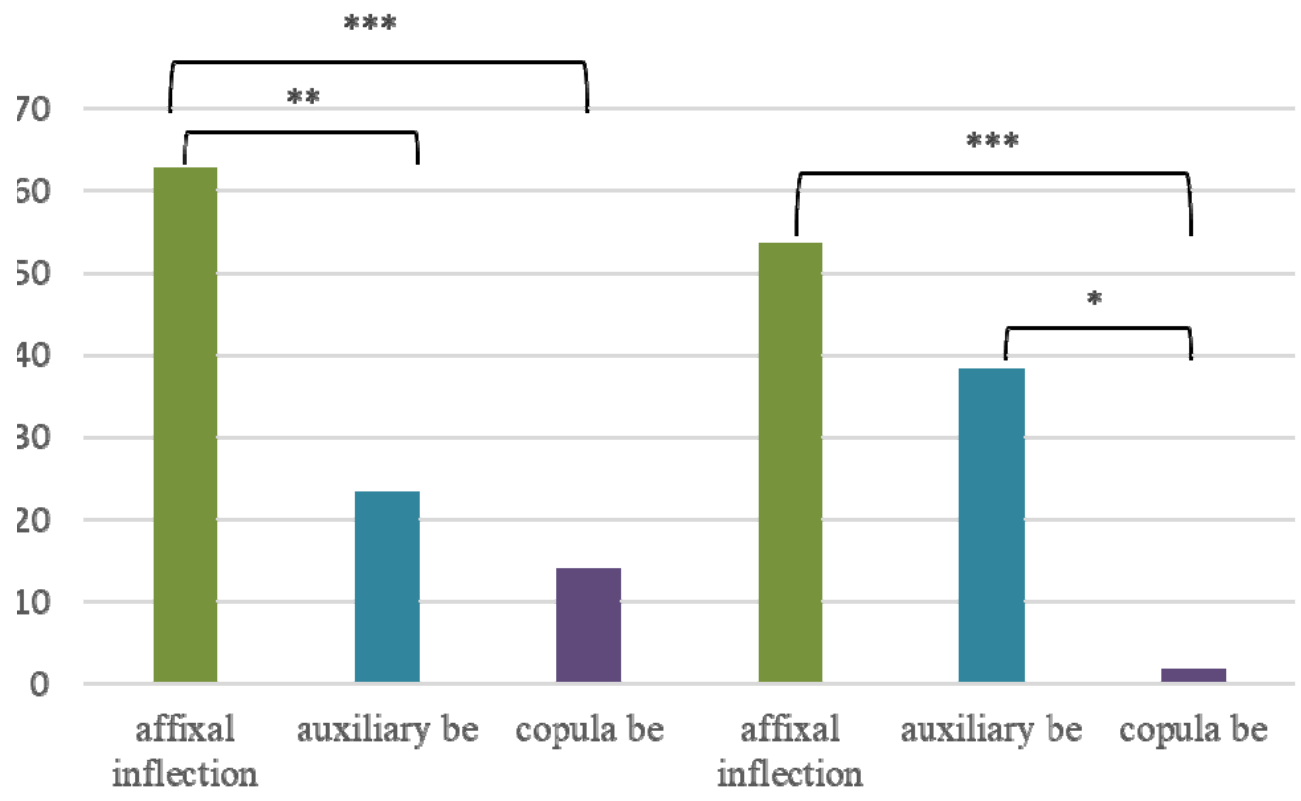

The results clearly indicate that affixal inflection is by far the most problematic context of the three: the omission of affixal inflection is the most common error made by both CLIL and non-CLIL groups, followed by the omission of the auxiliary be and, less commonly, the elision of copula be (in line with data from older learners in García Mayo \& Villarreal Olaizola, 2011; Villarreal Olaizola, 2011; Villarreal Olaizola 
\& Garcia Mayo, 2009). In the case of the CLIL group, despite the high omission of affixal inflection in lexical verbs, the significantly lower rate of omission of suppletive inflection points to a considerably better mastery of both copula and auxiliary be. The non-CLIL group, in contrast, still shows greater difficulties with auxiliary be, which they very frequently omit.

\subsubsection{Commission errors}

Commission errors are extremely rare in the sample investigated, as Figure 3 further illustrates. Even so, in the CLIL group, unlike with the omission trends presented above, it is copula be that is produced incorrectly at a significantly higher rate (10.91\%) than affixal inflection $(0.22 \%)\left(z=-2.207, p=.027^{*}\right)$. Auxiliary be was found to be produced erroneously more often $(1.59 \%)$ than the inflection in lexical verbs but remarkably less frequently than the inflection of copula be. None of these differences found statistical support, though. In the case of the non-CLIL group, although the commission error rate of the copula $(3.33 \%)$ was higher than that of affixal inflection $(1.78 \%)$, the difference is not statistically significant either. In this group, unlike in its CLIL homologous, commission errors of the auxiliary be were not attested.

Figure 3: Mean percent and Wilcoxon test results for commission errors

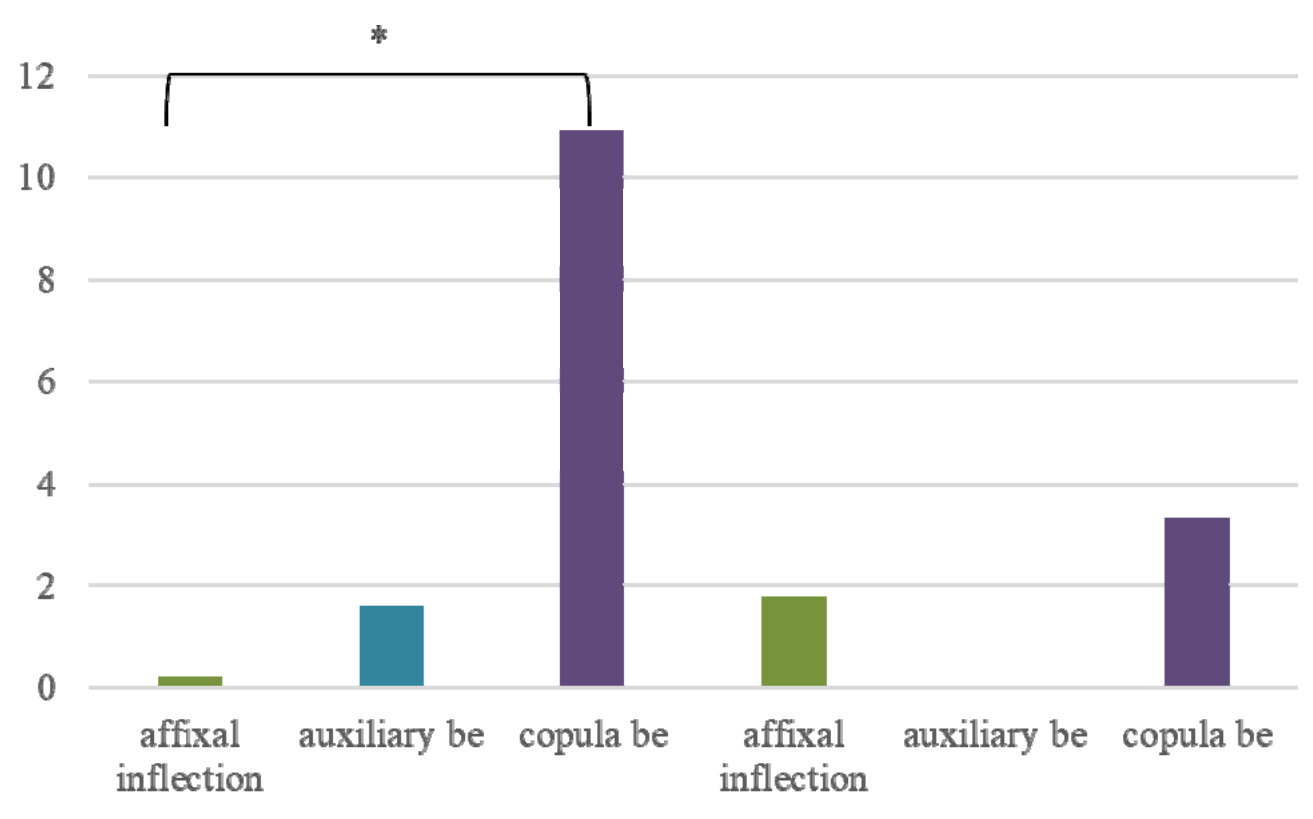

$$
\text { CLIL }
$$


The data obtained in this study comes to confirm prior results and claims with data from older learners inasmuch as the erroneous production of inflection is a very marginal characteristic of the L2 learners' grammar (García Mayo \& Villarreal Olaizola, 2011; Villarreal Olaizola, 2011; Villarreal Olaizola \& García Mayo, 2009). Although there seems to be a subtle trend indicating that commission errors are more frequent with copula be compared to affixal inflection, the rates of commission in the three verbal contexts are too low to draw categorical conclusions in this regard.

\subsubsection{Subject contexts}

Figure 4 shows that CLIL and non-CLIL learners were found to omit referential subjects very infrequently (3.53\% and $2.41 \%$, respectively) compared with expletive subjects (CLIL: 56.52\%, non-CLIL: 63.46\%). The rate of omission of expletive subjects is significantly higher than that of referential subjects in both the CLIL ( $z=$ -

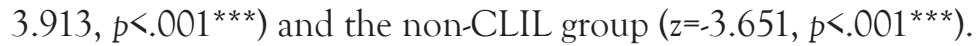

Figure 4: Mean percent and Wilcoxon test results for subject omission

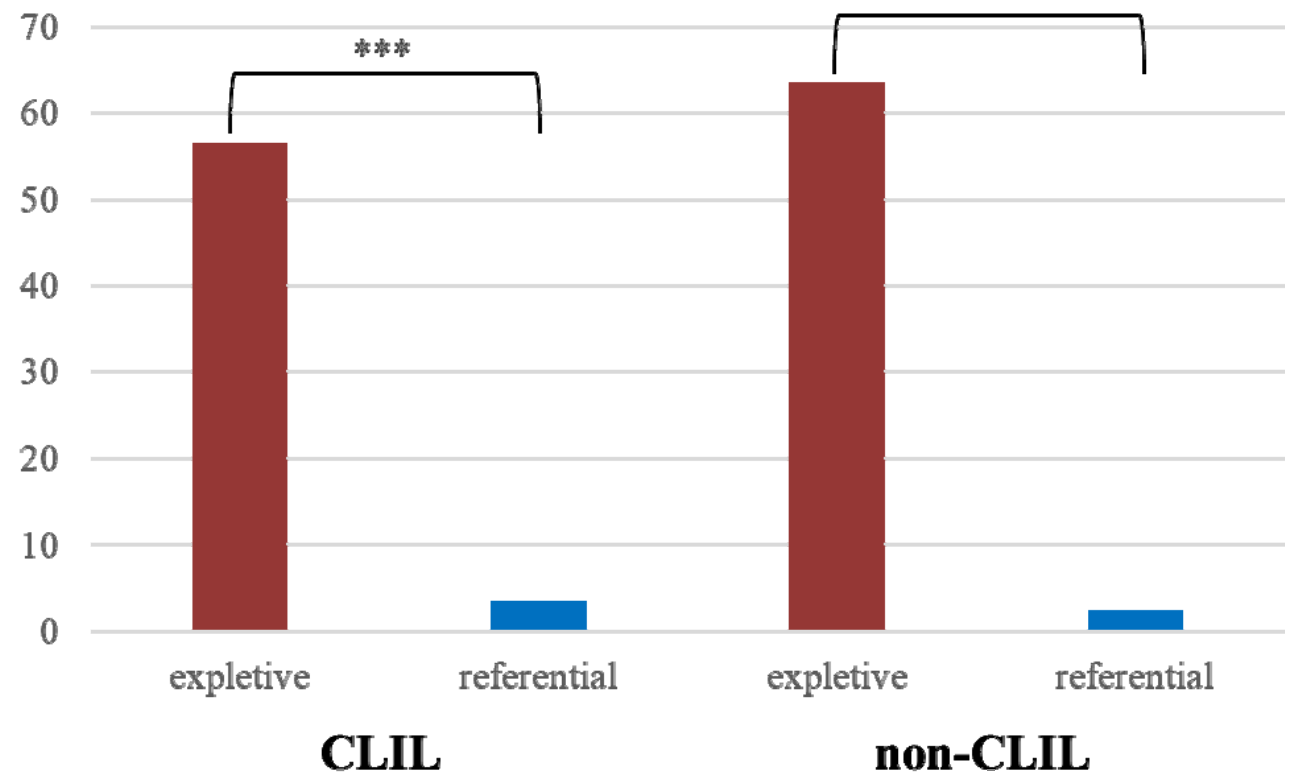

CLIL and non-CLIL learners thus behave alike in the provision of obligatory subjects in English. The fact that expletive subjects are significantly more problematic than referential subjects for both groups, especially for the non-CLIL learners, comes as no surprise, owing to the fact that expletive subjects have been claimed to entail 
important complications for learners with pro-drop L1s such as Spanish (in line with studies in non-CLIL contexts such as White's, 1986, 1989, 2003b).

\subsection{Discussion}

This section elaborates on the data presented above to tackle first the conclusions from the between group comparisons and then the implications of the within-groups analysis.

Our first research question addressed the potential intergroup comparisons in terms of the provision of agreement morphology and overt subjects. Our data suggest that, overall, additional long-term CLIL exposure at a younger age does not have a significantly strong impact on the learners' L2 English grammar compared to EFL instruction, at least in the sample under analysis here. Still, the CLIL L2 learners who participated in this investigation do show a somehow more target-like performance than the learners enrolled in traditional EFL lessons only. This can be observed in the former's lower omission rate of expletive subjects, minor incidence of placeholder is and better command of auxiliary be. None of these trends found statistical support, but this fact does not preclude the observation of latent and insightful trends which help to shed light on the current discussion. Even though the use of placeholder is is agreed to signal an early stage of the acquisition of L2 English, our data reveal that this resource is half as common in the CLIL group as in the non-CLIL one. Closely related to this is the fact that CLIL learners show a lower omission rate and a negligible commission rate of auxiliary be. This result is relevant inasmuch as it has been previously attested in EFL contexts and with older learners that this auxiliary is acquired earlier than other auxiliary verbs and it plays a decisive role in resetting the unmarked null subject parameter in their L1 (i.e. Spanish) to the marked (i.e. non-pro-drop) value in the L2 English (Ruiz de Zarobe, 1998). It has also been observed that it is the CLIL group that performed slightly better as regards the provision of expletive subjects, though transfer from their null-subject L1 is still considerably frequent. The fact that Spanish lacks purely grammatical subjects like the English expletive pronouns it and there makes it quite difficult for these learners to understand their obligatoriness and thus to rapidly acquire a target-like performance in this respect. In sum, although it is true that the CLIL learners in this sample are far from having a target-like performance in terms of inflectional morphology and obligatory subjects, the previous observations point to a subtly more advanced morphosyntactic stage of these learners over their (age-matched) non-CLIL homologous.

The lack of highly significant differences between the provision of inflectional morphology and overt subjects between the CLIL and non-CLIL learners may stem 
from two different factors. On the one hand, the age of the participants in this study. There is evidence in prior literature of the importance of age at testing, with older EFL learners outperforming younger CLIL and non-CLIL groups (Martínez Adrián \& Gutiérrez Mangado, 2015a; Villarreal Olaizola, 2011), and also age of first exposure, with larger exposure being translated into faster rates of acquisition only when the child achieves a somehow mature cognitive development (Lázaro Ibarrola, 2012; cf. Lázaro Ibarrola, 2002 and Muñoz, 2006 on additional exposure at earlier stages). Lázaro Ibarrola $(2002,2012)$ observes that three years of additional CLIL exposure in a group of 15 years-olds who had been exposed to English since they were 5 explains the learners' higher provision of irregular past forms and the fact that they do not use placeholder is compared to EFL learners, while their production of affixal morphemes does not differ significantly from that of their EFL homologous. Our study complements these results by exploring learners with a similar onset age (5-6) but with an earlier age at testing (11-12) and a longer additional CLIL exposure (6 years). With it, we show that long-term exposure through CLIL (cf. Lázaro Ibarrola, 2002 and Muñoz, 2006 on EFL contexts) does not result in a significantly faster rate of acquisition compared to EFL instruction, but only in certain positive signs of a slightly advanced stage of acquisition. The age at testing may well have conditioned our results in that our learners seem not to have reached yet the stage at which the acquisition of morphosyntactic features accelerates, at around 12-13 (Lázaro Ibarrola, 2002, 2012). In this sense, it would be interesting to examine the morphosyntactic development of these learners longitudinally, when they surpass that age, whether they are still enrolled in CLIL programmes or not (as in Villarreal Olaizola, 2011, where the positive effect of three years of CLIL disappears one year after the CLIL Secondary Education programme is over).

On the other hand, the focus on meaning and communicative interaction that characterises CLIL programmes might be also at play in the lack of significant intergroup comparisons. In line with previous studies, our investigation underscores the fact that "mere exposure to quantity and quality input seems not to be enough to develop productive skills or accuracy rates to a target-like level" (Villarreal Olaizola, 2011: 205); otherwise, the extra 488 hours of exposure that the CLIL group has received in addition to their EFL lessons should have translated in a significantly better and more target-like performance than the group receiving EFL instruction only. As a matter of fact, our research calls for a focus on form in CLIL programmes and, particularly, for "grammar instruction [...] in context" (Slabakova, 2008, p. 407), as "[t] he explicit knowledge acquired in their EFL lessons [...] might be hard to retrieve in the context of communicative interaction" (Martínez Adrián \& Gutiérrez Mangado, 2015a, p. 69; see also Ellis, 2001; García Mayo \& Villarreal Olaizola, 2011; Martínez Adrián \& Gutiérrez Mangado, 2015a; Muñoz, 2007; Pérez-Vidal, 2007; Pica, 2002; 
Villarreal Olaizola, 2011). This is particularly relevant for the acquisition of affixal inflection, for which exposure alone has been claimed to be insufficient for a targetlike performance (García Mayo \& Villarreal Olaizola, 2011), owing to the fact that it is "often perceived as semantically redundant and having little communicative value" (Pawlak, 2008: 188). Although the third person morpheme has been found to be acquired rather late compared to other morphemes, there is evidence of the positive impact of planned form-focused instruction on its acquisition. Pawlak (2008), for instance, found that teenage Polish L2 English learners were more target-like in the provision of third person $-s$ after treatment sessions with implicit corrective feedback in the form of recasts and output enhancement (i.e. clarification requests). More relevant is Basterrechea and García Mayo's (2014) study, where teenage CLIL learners were found to benefit from form-focused instruction through dictoglosses, with CLIL learners showing a higher - though non-significant - provision of affixal inflection than their EFL homologous, especially when the task was completed in pairs.

Our second research question focused on the intragroup differences as to the two main features under analysis: agreement morphology errors and null subjects. In this regard, one must consider that this investigation explores the learners' oral production, so the processing difficulties and pressure that this task may involve for the learner must not be underestimated. In the case of affixal inflection, for instance, this often results in the use of uninflected forms as the default option (Ionin, 2013; Prévost \& White, 2000; cf. Villarreal Olaizola, 2011 on written data). Still, the general trends observed in this study conform to what previous studies on older learners have attested: a higher omission of affixal compared to suppletive inflection (as in García Mayo \& Villarreal Olaizola, 2011; Villarreal Olaizola \& García Mayo, 2009; Villarreal Olaizola, 2011). As discussed above, the explanation to this finding is rooted in minimalist theory, with copula and auxiliary be checking their agreement and tense features overtly and thus expressed morphologically, and lexical verbs checking theirs covertly, with or without overt morphological expression (Ionin \& Wexler, 2002). This difference makes it more complicated for learners to achieve a target-like performance in this respect (García Mayo \& Villarreal Olaizola, 2011), as the young learners who participated in this study demonstrated. Their performance has nonetheless conformed to the well-attested asymmetry between affixal and suppletive morphology, as is evident from their overall greater mastery of suppletive over affixal inflection and copula be over auxiliary be. Although the CLIL learners do show an apparent more target-like provision of suppletive inflection, their problems with affixal morphology and null subjects do not differ significantly from the non-CLIL group's morphosyntax. Hence, it seems that our data provide support for previous claims on the provision of these morphosyntactic features being independent of the type of instruction and increased exposure (García Mayo \& Villarreal Olaizola, 2011; Martínez Adrián \& Gutiérrez Mangado, 2015a; Villarreal Olaizola, 2011; Villarreal Olaizola \& García Mayo, 2009). 
The results also indicate that the grammar of our young L2 English learners seems to be unimpaired. Both the CLIL and non-CLIL learners in this study were found to have a good mastery of referential subjects but, at their early age, the input they have received may not have been enough to acquire the obligatory use of expletive subjects. Their use of placeholder is also evidences a quite underdeveloped L2 inflectional system (cf. the better performance of the slightly older L2 learners in Lázaro Ibarrola, 2012; Martínez Adrián \& Gutiérrez Mangado, 2009), even in the case of the group that receives long-term additional exposure to the target language through CLIL instruction. However, while both CLIL and non-CLIL learners have certain problems to supply the inflected forms correctly, particularly the third person singular bound morpheme, they nonetheless seem well aware of the erroneous placement of affixal inflection in contexts other than the third person singular as well as of the wrong provision of inflected suppletive forms. Accordingly, they do not use inflectional morphology unsystematically; they use a high rate of bare uninflected forms as a default instead and barely produce commission errors, which points in the opposite direction of a possible representational impairment as regards agreement morphology (see Ionin \& Wexler, 2002). This result is in keeping with previous investigations with older learners which claim that errors and variability in the provision of inflection just result from a mapping problem whereby learners are not able to supply the correct inflectional form even though both tense and agreement features are already available in their L1 (i.e. Spanish in this case) (García Mayo \& Villarreal Olaizola, 2011; Villarreal Olaizola, 2011). An exception to this trend is copula be in our CLIL group. Its slightly higher commission error rate (significantly higher than that of affixal inflection) has, to the best of our knowledge, no prior antecedents in the literature, which calls for further research to try to determine the source of this unexpected finding. As a tentative hypothesis, we argue that this divergent trend may stem from the CLIL approach itself. It must be taken into account that, on the one hand, CLIL lessons have been claimed to focus more on meaning than on form in comparison with traditional EFL classes (Martínez Adrián, 2011) and, on the other, corrective feedback has been found to be less frequent in CLIL than in EFL settings (Milla \& García Mayo, 2014), two aspects which may well have had an effect on the data attested in this investigation and, thus, should not be disregarded. The variety of forms that copula be takes might be regarded as an alternative explanation, but it seems unlikely in view of the lower rate of commission of auxiliary be in these same learners.

\section{Conclusions}

The main aim of this paper is to contribute to the existing debate on the potential benefits of CLIL programmes for the learner's L2 English morphosyntax with data from the Spanish monolingual community of Cantabria. To this end, we assessed 
the potential impact of an early start and a long-term exposure to the target language through CLIL instruction on young (11- and 12-year-old) English learners' provision of agreement morphology and overt subjects, compared to age-matched learners with the same onset age but enrolled in traditional EFL programmes. Our investigation reveals that the provision of specific morphosyntactic characteristics such as inflection and obligatory subjects do not benefit so clearly from an earlier start and longer exposure to English through the increasingly popular CLIL programmes. Although we did find positive results for the CLIL group that point to a potential impact of CLIL instruction, such as a lower rate of placeholder is and null subjects, the effect of CLIL on these Spanish young learners' English morphosyntax is not highly significant compared to traditional EFL instruction.

In keeping with prior literature on the topic with older Spanish L2 English learners, our findings suggest that CLIL programmes may be more effective for the right provision of agreement morphology and overt subjects. Nonetheless, our research also calls for further focus on form and corrective feedback in CLIL programmes to achieve greater effectiveness and to try to minimise one of the well-attested weaknesses of this educational approach (Ball, 2016; Ball et al., 2015). These observations thus need further research to gauge the effect of implicit corrective feedback (Milla \& García Mayo, 2014) and collaborative tasks (for Primary School learners, see García Mayo \& Imaz Aguirre, 2019; for adult learners, García Mayo \& Azkarai Garai, 2016 and Payant \& Kim, 2019) on the learner's attention to form while engaged in meaning-focused communicative interaction. The triangulation with qualitative data coming from the observations of CLIL lessons can further provide insight into more effective ways of integrating the focus on formal aspects into content lessons. CLIL instructors should ideally receive training courses where the language component of their lessons is highlighted. They must be empowered so that they are able to identify the key language needed for their content units, make it more salient (Ball, 2016), and incorporate activities where students' knowledge of English grammar is called upon in order to process content information (see Ting, 2011). As clear from cross-linguistic influence being the source of some of the errors reported (e.g. subject omission), it is also suggested that CLIL instructors do not treat English in isolation from students' L1, a recommendation which holds true for EFL teachers as well.

The investigation has nonetheless some limitations. Firstly, the instrument used to collect the data complicates the comparison with homologous investigations using the story Frog, where are you? (e.g. García Mayo \& Villarreal Olaizola, 2011; Villarreal Olaizola, 2011; Villarreal Olaizola \& García Mayo, 2009). Secondly, it is necessary to compare these results with the learners' written production to gauge the potential effect of the processing difficulties and pressure inextricably linked to the oral task on 
their provision of the morphosyntactic features surveyed (as in Villarreal Olaizola's 2011 tentative approximation).

This investigation would also benefit from an in-depth analysis of sequences which have not been included here but could provide insightful observations on both inflection and subject omission, such as utterances involving autocorrection and repair sequences, with which Martínez Adrián and Gutiérrez Mangado (2015a) observed an impact of the focus on meaning of CLIL instruction on the low number of successfully repaired sequences by teenage Spanish L3 English learners (also Lázaro \& García Mayo, 2012). In view of the fairly high standard deviations in the data reported, it is necessary to carry out a more fine-grained exploration of individual trends. It would also be very interesting to measure the learners' target-like performance by assessing their frequency in use of affixal morphology and explore the relation between finiteness and subject omission, as both aspects will surely help to shed light on the observations and claims presented in this paper. Another aspect that would reward further research on the potential differences between our CLIL and non-CLIL learners is the examination of other morphosyntactic features and forms, as is the case of the past inflection (as in García Mayo \& Villarreal Olaizola, 2011; Lázaro Ibarrola, 2012; Martínez Adrián \& Gutiérrez Mangado, 2015a; Villarreal Olaizola, 2011; Villarreal Olaizola \& García Mayo, 2009) and article omission and overuse (as in Gutiérrez-Mangado \& MartínezAdrián, 2018). As a final remark, designs where different degrees of intensity of the CLIL programme are compared (see Merino \& Lasagabaster, 2018), particularly with a longitudinal research approach, should be welcome.

\section{Acknowledgements}

This research is part of the project Bilingual teaching and learning in Cantabria: From primary to tertiary education, funded by the University of Cantabria (ref. UC2016GRE-10). We are also grateful to the Primary Schools, the students and the teachers who agreed to participate in this study, as well as to Pedro Alberto San Emeterio Bolado for the vignettes.

\section{References}

Aguilar, M. \& Muñoz, C. (2014) The effect of proficiency on CLIL benefits in Engineering students in Spain. International Journal of Applied Linguistics, 24(1), 1-18.

Ball, P. (2016). Using language(s) to develop subject competences in CLIL-based practice. Pulso. Revista de educación, 39, 15-34. 
Ball, P., Kelly, K. \& Clegg, J. (2015) Putting CLIL into Practice. Oxford: Oxford University Press.

Basterrechea, M. \& García Mayo, M. P. (2014) Dictogloss and the production of the English third person $-s$ by CLIL and mainstream EFL learners: A comparative study. International Journal of English Studies, 14(2), 77-98.

Blanco-Suárez, Z., Gallardo-del-Puerto, F. \& Gandón-Chapela, E. (2020) The Primary Education Learners' English Corpus (PELEC): Design and compilation. RiCL, Research in Corpus Linguistics, 8(1), 147-163.

Brown, R. (1973) A First Language: The Early Stages. Cambridge, MA: Harvard University Press.

Cadierno, T., Hansen, M., Lauridsen, J. T., Eskildsen, S. W, Fenyvesi, K., Jensen, S. H. \& aus der Wieschen, M. V. (2020) Does younger mean better? Age of onset, learning rate and short-term L2 proficiency in young Danish learners of English. Vigo International Journal of Applied Linguistics, 17, 57-86.

Chomsky, N. (1981) Lectures on Government and Binding. Dordrecht: Foris.

Coyle, D. (2010) Foreword. In D. Lasagabaster \& Y. Ruiz de Zarobe (eds) CLIL in Spain: Implementation, Results and Teacher Training. (pp. vii-viii) Newcastle upon Tyne: Cambridge Scholars.

Dalton-Puffer, C. (2008) Outcomes and processes in Content and Language Integrated Learning (CLIL): Current research from Europe. In W. Delanoy \& L. Volkmann (eds) Future Perspectives for English Language Teaching. (pp. 139-157) Heidelberg: Carl Winter.

Ellis, R. (2001) Introduction: Investigating form-focused instruction. Language Learning, 51(s1), 1-46.

Eurydice. (2006) Content and Language Integrated Learning at School in Europe. Brussels: Eurydice European Unit.

Fernández Fontecha, A. (2009) Spanish CLIL: Research and official actions. In Y. Ruiz de Zarobe \& R. M. Jiménez Catalán (eds) Content and Language Integrated Learning: Evidence from Research in Europe. (pp. 3-21) Clevedon: Multilingual Matters.

Gallardo del Puerto, F., Gómez Lacabex, E \& García Lecumberri, M. L. (2009) Testing the effectiveness of Content and Language Integrated Learning in foreign language contexts: The assessment of English pronunciation. In Y. Ruiz de Zarobe \& R. M. Jiménez Catalán (eds) Content and Language Integrated Learning: Evidence from Research in Europe. (pp. 63-80) Clevedon: Multilingual Matters. 
\& Martínez Adrián, M. (2013) ¿Es más efectivo el aprendizaje de la lengua extranjera en un contexto AICLE? Resultados de la investigación en España. Padres y Maestros, 34, 25-28.

García Mayo, M. P. (2003) Age, length of exposure and grammaticality judgments in the acquisition of English as a foreign language. In M. P. García Mayo \& M. L. García Lecumberri (eds) Age and the Acquisition of English as a Foreign Language. (pp. 94-114) Clevedon: Multilingual Matters.

\& Azkarai Garai, A. (2016) EFL task-based interaction: Does task modality impact on language-related episodes? In M. Sato \& S. Ballinger (eds) Peer Interaction and Second Language Learning: Research Agenda and Pedagogical Implications. (pp. 241-266) Amsterdam \& Philadelphia: John Benjamins.

\& Imaz Agirre, A. (2019) Task modality and pair formation method: Their impact on patterns of interaction and attention to form among EFL primary school children. System: An International Journal of Educational Technology and Applied Linguistics, 80, 165-175.

, Lázaro Ibarrola, A. \& Liceras, J. M. (2005) Placeholders in the English interlanguage of bilingual (Basque/Spanish) children. Language Learning, 55(3), 445 489.

\& Villarreal Olaizola, I. (2011) The development of suppletive and affixal tense and agreement morphemes in the L3 English of Basque-Spanish bilinguals. Second Language Research, 27(1), 129-149.

Goad H., White, L. \& Steele, J. (2003) Missing inflection in L2 acquisition: Defective syntax or L1-constrained prosodic representations? Canadian Journal of Linguistics, 48, 243-263.

Guilfoyle, E. (1984) The acquisition of tense and the emergence of thematic subjects in child grammars of English. The McGill Working Papers in Linguistics, 2, 20-30.

Gutiérrez-Mangado, M. J. \& Martínez-Adrián, M. (2018) CLIL at the linguistic interfaces. International Journal of Immersion and Content-Based Education, 6(1), 85-112.

Gutiérrez Martínez, A. \& Ruiz de Zarobe, Y. (2017) Comparing the benefits of a metacognitive reading strategy instruction programme between CLIL and EFL Primary School students. Estudios de Lingüistica Inglesa Aplicada, 17, 71-92.

Hawkins, R. \& Casillas, G. (2008) Explaining frequency of verb morphology in L2 early speech. Lingua, 118, 595-612.

\& Chan, Y-C. (1997) The partial availability of Universal Grammar in second language acquisition: The 'failed features' hypothesis. Second Language Research, 13, $187-226$. 
Haznedar, B. (2001) The acquisition of the IP system in child L2 English. Studies in Second Language Acquisition, 23, 1-39.

\& Schwartz, B. (1997) Are there optional infinitives in child L2 acquisition? In E. Hughes, M. Hughes \& A. Greenhill (eds) Proceedings of the 21 $1^{\text {st }}$ Boston University Conference on Language Development. (pp. 257-268) Somerville, MA: Cascadilla Press.

Hyams, N. (1989) The Null Subject Parameter in language acquisition. In O. Jaeggli \& N. Hyams (eds) The Null Subject Parameter. (pp. 215-238) Dordrecht: Kluwer.

Ionin, T. (2013) Morphosyntax. In J. Herschensohn \& M. Young-Scholten (eds) The Cambridge Handbook of Second Language Acquisition. (pp. 505-528) Cambridge: Cambridge University Press.

\& Wexler, K. (2002) Why is 'is' easier than 's'?: Acquisition of tense/ agreement morphology by child second language learners of English. Second Language Research, 18, 95-136.

Jessner, U. (2014) On multilingual awareness or why the multilingual learner is a specific language learner. In M. Pawlak \& L. Aronin (eds) Essential Topics in Applied Linguistics and Multilingualism: Studies in Honor of David Singleton. (pp. 175-184) Wien: Springer.

Jiménez Catalán, R. M., Ruiz de Zarobe, Y. \& Cenoz, J. (2006) Vocabulary profiles of English foreign language learners in English as a subject and as a vehicular language. Vienna English Working Papers, 15(3), 23-27.

Juan-Garau, M. \& Pérez Vidal, C. (2011) Trilingual primary education in the Balearic Islands. In I. Bangma, C. van der Meer \& A. Riemersma (eds) Trilingual Primary Education in Europe: Some Developments with Regard to the Provisions of Trilingual Primary Education in Minority Language Communities of the European Union. (pp. 129-142) Leeuwarden: Fryske Akademy.

Judy, T. (2011) L1/L2 parametric directionality matters: More on the Null Subject Parameter in L2 acquisition. EUROSLA Yearbook, 11, 165-190.

\& Rothman, J. (2010) From a superset to a subset grammar and the semantic compensation hypothesis: Subject pronouns and anaphora resolution in L2 English. In K. Franich, K. M. Iserman \& L. L. Keil (eds) BUCLD 34: Proceedings of the 34 th Annual Boston University Conference on Language Development. (pp. 197-208) Sommerville, MA: Cascadilla Press.

Lardiere, D. (2000) Mapping features to forms in second language acquisition. In J. Archibald (ed) Second Language Acquisition and Linguistic Theory. (pp. 102-129) Cambridge, MA: Blackwell. 
. (2008) Feature assembly in second language acquisition. In J. M. Liceras, H. Zobl \& H. Goodluck (eds) The Role of Formal Features in Second Language Acquisition. (pp. 106-140) New York: Lawrence Erlbaum Associates.

. (2009) Some thoughts on the contrastive analysis of features in second language acquisition. Second Language Research, 25(2), 173-227.

Lasagabaster, D. (2008) Foreign language competence and language integrated courses. The Open Applied Linguistics Journal, 1, 31-42.

Lázaro Ibarrola, A. \& García Mayo, M. P. (2012) L1 use and morphosyntactic development in the oral production of EFL learners in a CLIL context. International Review of Applied Linguistics, 50, 135-160.

Lázaro Ibarrola, A. (2002) La Adquisición de la Morfosintaxis del Inglés por Niños Bilingües Euskera/Castellano: Una Perspectiva Minimalista. Unpublished PhD dissertation. Department of English and German, University of the Basque Country (Spain).

. (2012) Faster and further morphosyntactic development of CLIL vs. EFL Basque-Spanish bilinguals learning English in High-School. International Journal of English Studies, 12(1), 79-96.

MacWhinney, B. (2000) The CHILDES Project: Tools for Analyzing Talk. Third Edition. Mahwah, NJ: Lawrence Erlbaum Associates.

Marsh, D. (1994) Bilingual Education $\mathcal{E}$ Content and Language Integrated Learning. Paris: International Association for Cross-cultural Communication, Language Teaching in the Member States of the European Union (Lingua) University of Sorbonne.

. (ed) (2002) CLIL/EMILE - The European Dimension: Actions, Trends and Foresight Potential. Brussels: The European Commission.

Martínez Adrián, M. (2011) An overview of Content and Language Integrated Learning: Origins, features and research outcomes. Huarte de San Juan. Filología y Didáctica de la Lengua, 11, 93-101.

\& Gutiérrez Mangado, M. J. (2009) The acquisition of English syntax by CLIL learners in the Basque Country. In Y. Ruiz de Zarobe \& R. M. Jiménez Catalán (eds) Content and Language Integrated Learning: Evidence from Research in Europe. (pp. 176196) Clevedon: Multilingual Matters.

\& Gutiérrez Mangado, M. J. (2015a) Is CLIL instruction beneficial in terms of general proficiency and specific areas of grammar? Journal of Immersion and ContentBased Language Education, 3(1), 51-76.

\& Gutiérrez Mangado, M. J. (2015b) L1 use, lexical richness, accuracy and complexity in CLIL and NON-CLIL learners. Atlantis, Journal of the Spanish Association for Anglo-American Studies, 37(2), 175-200. 
Merino, J. A. \& Lasagabaster, D. (2018) The effect of Content and Language Integrated Learning programmes' intensity on English proficiency: A longitudinal study. Journal of Applied Linguistics, 28, 18-30.

Milla, R. \& García Mayo, M. P. (2014) Corrective feedback episodes in oral interaction: A comparison of a CLIL and an EFL classroom. International Journal of English Studies, 14(1), 1-20.

Montrul, S. (2011) Multiple interfaces and incomplete acquisition. Lingua, 121, 591-604.

Muñoz, C. (2002) Relevance and potential of CLIL. In D. Marsh (ed) CLIL/ EMILE - The European Dimension: Actions, Trends and Foresight Potential. (pp. 33-36) Brussels: The European Commission.

. (2006) Accuracy orders, rate of learning and age in morphological acquisition. In C. Muñoz (ed) Age and the Rate of Foreign Language Learning. (pp. 107-125) Clevedon: Multilingual Matters.

. (2007) CLIL: Some thoughts on its psycholinguistic principles. RESLA, Revista Española de Lingüistica Aplicada, 20, 17-26.

Navés, T. \& Victori, M. (2010) CLIL in Catalonia: An overview of research studies. In D. Lasagabaster \& Y. Ruiz de Zarobe (eds) CLIL in Spain: Implementation, Results and Teacher Training. (pp. 30-54) Newcastle upon Tyne: Cambridge Scholars.

Ortega Durán, M. (2016) Crosslinguistic Influence in L2 English Oral Production: The Effects of Cognitive Language Learning Abilities and Input. Unpublished $\mathrm{PhD}$ dissertation. Department of Modern Language and Literatures and of English Studies, University of Barcelona (Spain).

Pawlak, M. (2008) The effect of corrective feedback on the acquisition of the English third-person $-s$ ending. In D. Gabry-Barker (ed) Morphosyntactic Issues in Second Language Acquisition. (pp. 187-202) Clevedon: Multilingual Matters.

Payant, C. \& Kim, Y. (2019) Impact of task modality on collaborative dialogue among plurilingual learners: A classroom-based study. International Journal of Bilingual Education and Bilingualism, 22(5), 614-627.

Pérez-Cañado, M. L. (2012) CLIL research in Europe: Past, present, and future. International Journal of Bilingual Education and Bilingualism, 15(3), 315-341.

Pérez-Vidal, C. (2007) The need for Focus on Form (FoF) in Content and Language Integrated approaches: An exploratory study. RESLA, Revista Española de Lingüística Aplicada, 1, 39-45.

\& Juan-Garau, M. (2010) To CLIL or not to CLIL? From bilingualism to multilingualism in Catalan/Spanish communities in Spain. In D. Lasagabaster \& Y. 
Ruiz de Zarobe (eds) CLIL in Spain: Implementation, Results and Teacher Training. (pp. 115-139) Newcastle upon Tyne: Cambridge Scholars.

\& Juan-Garau, M. (2011) Trilingual Primary Education in Catalonia. In I. Bangma, C. van der Meer \& A. Riemersma (eds) Trilingual Primary Education in Europe: Some Developments with Regard to the Provisions of Trilingual Primary Education in Minority Language Communities of the European Union. (pp. 68-92) Leeuwarden: Fryske Akademy.

$\&$ Roquet, H. (2015) The linguistic impact of a CLIL Science programme: An analysis measuring relative gains. System, 54, 80-90.

Phinney, M. (1987) The Pro-Drop Parameter in second language acquisition. In T. Roeper \& E. Williams (eds) Parameter Setting. (pp. 221-238) Dordrecht: D. Reidel.

Pica, T. (2002) Subject matter content: How does it assist the interactional and linguistic needs of classroom language learners? The Modern Language Journal, 86(1), $1-19$.

Pladevall Ballester, E. (2012) Child L2 English acquisition of subject properties in an immersion bilingual context. Second Language Research, 28(2), 217-241.

. (2013) Adult instructed SLA of English subject properties. Canadian Journal of Linguistics, 58(3), 465-486.

Prévost, P. \& White, L. (2000) Missing surface inflection or impairment in second language acquisition? Evidence from tense and agreement. Second Language Research, $16,103-133$.

Rizzi, L. (1993) Some notes on linguistic theory and language development: The case of root infinitives. Language Acquisition, 3(4), 371-393.

Ruiz de Zarobe, Y. (1997) Comportamiento de los pronombres expletivos en inglés: Aspectos contrastivos entre la primera y la segunda lengua. Cuadernos de Investigación Filológica, 23-24, 7-15.

(1998) Uniformidad morfológica y adquisición de sujetos en inglés lengua extranjera. Langues et Linguistique, 24, 171-186.

- (2000) Concordancia copulativa, pronombres sujeto y adquisición de sistemas no-nativos. Linguistica XL, 2, 327-333.

. (2007) CLIL in a bilingual community: Similarities and differences with the learning of English as a foreign language. Vienna English Working Papers, 16(3), 47-52.

. (2008) CLIL and Foreign Language Learning: A longitudinal study in the Basque Country. International CLIL Research Journal, 1(1), 60-73.

(2011) Which language competencies benefit from CLIL? An insight into applied linguistics research. In Y. Ruiz de Zarobe, J. Sierra \& F. Gallardo del Puerto 
(eds) Content and Foreign Language Integrated Learning: Contributions to Multilingualism in European Contexts. (pp. 129-153) Bern: Peter Lang.

\& Lasagabaster, D. (eds) (2010) CLIL in Spain: Implementation, Results and Teacher Training. Newcastle upon Tyne: Cambridge Scholars.

San Isidro, X. (2010) An insight into Galician CLIL: Provision and results. In D. Lasagabaster \& Y. Ruiz de Zarobe (eds) CLIL in Spain: Implementation, Results and Teacher Training. (pp. 55-78) Newcastle upon Tyne: Cambridge Scholars.

\& Lasagabaster, D. (2019a) The impact of CLIL on pluriliteracy development and content learning in a rural multilingual setting: A longitudinal study. Language Teaching Research, 23(5), 584-602.

\& Lasagabaster, D. (2019b) Code-switching in a CLIL multilingual setting: A longitudinal qualitative study. International Journal of Multilingualism, 16(3), 336-356.

Slabakova, R. (2008) Meaning in the Second Language. Berlin: Mouton de Gruyter.

Ting, T. (2011) CLIL and Neuroscience: How are they related? In Y. Ruiz de Zarobe, J. Sierra \& F. Gallardo del Puerto (eds) Content and Foreign Language Integrated Learning: Contributions to Multilingualism in European Contexts. (pp. 75-101) Bern: Peter Lang.

Tsimpli, I. M. \& Dimitrakopoulou, M. (2007) The interpretability hypothesis: Evidence from wh-interrogatives in second language acquisition. Second Language Research, 23, 215-242.

Villarreal Olaizola, I. (2011) Tense and Agreement in the Non-Native English of Basque-Spanish Bilinguals: Content and Language Integrated Learners vs. English as a School Subject Learners. Unpublished PhD dissertation. Department of English and German, University of the Basque Country (Spain).

\& García Mayo, M. P. (2009) Tense and agreement morphology in the interlanguage of Basque/Spanish bilinguals: CLIL versus non-CLIL. In Y. Ruiz de Zarobe \& R. M. Jiménez Catalán (eds) Content and Language Integrated Learning: Evidence from Research in Europe. (pp. 157-175) Clevedon: Multilingual Matters.

White, L. (1986) Implications of parametric variation for adult second language acquisition: An investigation of the Pro-Drop Parameter. In V. Cook (ed) Experimental Approaches to Second Language Acquisition. (pp. 55-72) Oxford: Pergamon.

. (1989) Universal Grammar and Second Language Acquisition. Amsterdam \& Philadelphia: John Benjamins.

. (2003a) Fossilization in steady state L2 grammars: Persistent problems with inflectional morphology. Bilingualism: Language and Cognition, 6(2), 129-141. 
. (2003b) Second Language Acquisition and Universal Grammar. Cambridge: Cambridge University Press.

Zobl, H. \& Liceras, J. (1994) Functional categories and acquisition orders. Language Learning, 44, 159-180.

\section{Appendix. The 8-vignette story used to collect the data}

1.

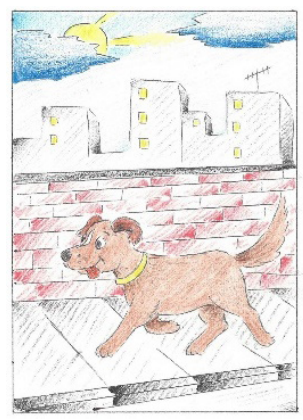

3.

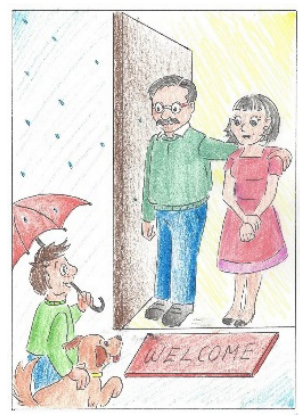

2.

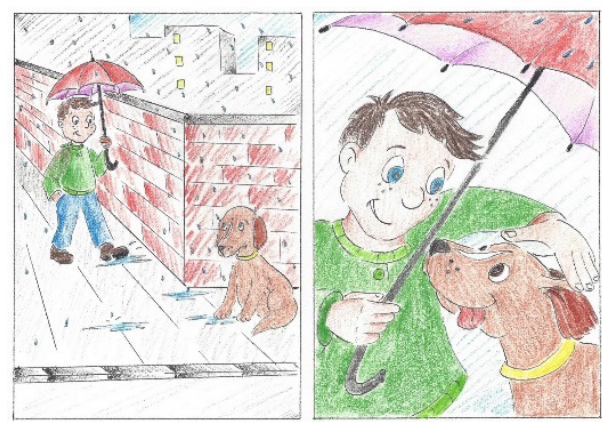

4.

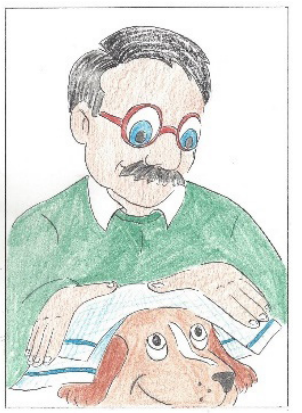

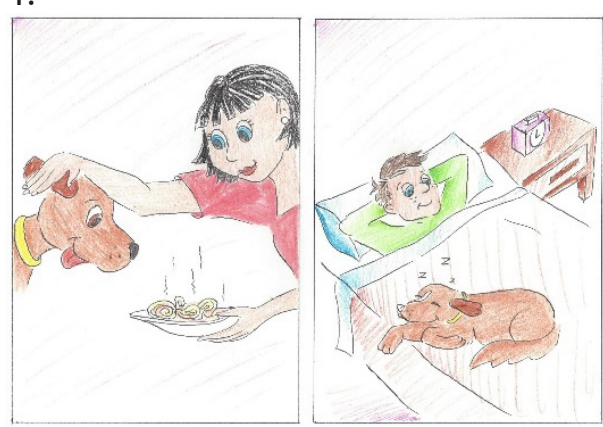


